\title{
2013 Cotton Defoliation and Harvest Aid Guide ${ }^{1}$
}

\author{
R. G. Leon, D. L. Wright, and B. J. Brecke ${ }^{2}$
}

In Florida, cotton requires about 155 days of growth from planting to harvest. Throughout the growing season, growers must make important management decisions about defoliation, boll opening, and regrowth suppression. These factors can affect the quality and storage time if the crop is put into modules. The greatest losses in quality are caused by stain from poorly defoliated plants or regrowth and moisture from green tissue.

There are several ways to determine when to defoliate cotton. An old rule of thumb is to defoliate when $60 \%-75 \%$ of the bolls are open. Another method is "nodes above cracked bolls" (shortened to NACB). Research has shown that cotton with four nodes above the highest cracked boll can be defoliated without significant losses in weight or quality. If NACB counts average five or more, defoliant applications should be delayed. Harvest aids work best when there is a good boll load and most of the nitrogen applied for the cotton crop has been used.

Experience with harvest aids (i.e., boll openers, regrowth retardants, desiccants, and mature and juvenile foliage removal) has shown that timing of the defoliant should be based on yield potential and quality of the mature, unopened bolls while considering the potential loss in yield and fiber from the already open bolls. The largest bolls are generally those that set early and low, nearest to the main stem of the plant. If early insect damage hindered fruiting, wait as long as possible before defoliating to allow the top crop to develop; the $60 \%-75 \%$ rule may not apply.

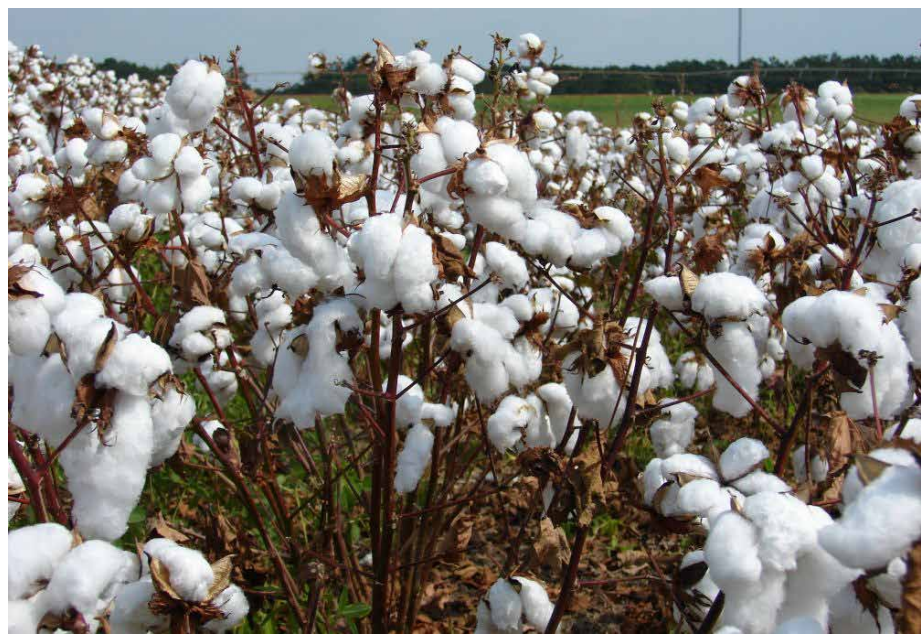

Figure 1. A cotton plant that has been defoliated for two weeks is shown in this September 2008 photo, taken at the University of Florida's North Florida Research and Education Center in Quincy, FL.

1. This document is SS-AGR-181, one of a series of the Agronomy Department, UF/IFAS Extension. First published: September 2002. Latest revision: October 2013. Visit the EDIS website at http://edis.ifas.ufl.edu.

2. R. G. Leon, assistant professor, West Florida Research and Education Center, Jay, FL; D. L. Wright, professor, North Florida Research and Education Center, Quincy, FL; and B. J. Brecke, professor emeritus, West Florida Research and Education Center, Jay, FL; UF/IFAS Extension, Gainesville, FL 32611.

The use of trade names in this publication is solely for the purpose of providing specific information. UF/IFAS does not guarantee or warranty the products named, and references to them in this publication does not signify approval of these products to the exclusion of other products of suitable composition.

Use pesticides safely. Read and follow directions on the manufacturer's label.

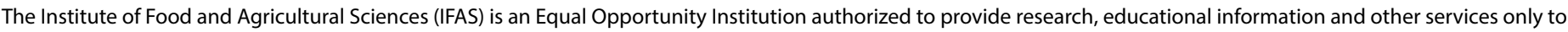

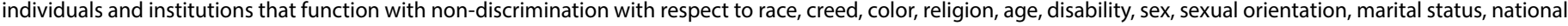
origin, political opinions or affiliations. For more information on obtaining other UF/IFAS Extension publications, contact your county's UF/IFAS Extension office. 
A crop that has set and retained most of the early fruit may be ready for defoliation at $50 \%$ open bolls. Also, where large acreage has to be harvested, growers may sacrifice some immature bolls that contribute little to the final yield, so that harvest can begin before adverse weather conditions reduce overall yield and quality of the crop. Bolls that set in mid-summer are usually larger and mature in 40-50 days. On the other hand, bolls that set in August can take 60 days or longer to mature and often contribute little to the final yield if the crop had a normal fruiting season. Those late flowers may look attractive and give the appearance of adding to the final yield of the crop, but do not give preference to them over the fruit that was set during the first three to four weeks of bloom. The fruit set during the first four weeks of bloom normally contributes $90 \%-95 \%$ of the total yield of the cotton crop.

Estimating the number of mature, open bolls in the field is helpful in scheduling the defoliant and boll opener. Under good growing conditions, ten mature bolls per foot of row produce a bale of cotton per acre. More bolls are needed if they are higher on the plant; fewer bolls are needed if they are lower on the plant. Counts should include (1) open bolls, including cracked bolls; (2) green bolls that are mature and string out when cut with a knife; and (3) immature bolls that are harvestable or will mature while conditions are favorable.

The crop should be defoliated in stages where large acreages are harvested. Harvest aids should be applied approximately 12-14 days ahead of picking. A four-row picker can pick about 40 acres a day in the early part of the season, but will pick less late in the season because of the shorter days.

There are different ways to defoliate cotton, and several harvest aid chemicals are available that work well in Florida. The choice depends on whether the cotton has normal growth, is rank, or has weed overgrowth; it also depends on the time of year. With rank cotton and cotton that has weed overgrowth, use a normal rate of defoliant and then come back with a second application to defoliate the bottom of the crop. Higher rates of defoliants may kill the plant and cause the leaves to stay attached, instead of allowing the crop to mature and form the abscission layer, resulting in leaf drop.

Drought stress and cool weather can make plants more difficult to defoliate, especially where high levels of nitrogen remain in the plant. High residual nitrogen in the soil and in the plant can result in regrowth as soon as moisture is available. The young, green leaves that appear in the terminal can stain the lint during the picking process. As the weather cools later in the season, harvest aids are less active.

Defoliants work in one of two ways, either by herbicidal action or hormonal activity. Some examples of herbicidal defoliants that injure plant leaves are the following: Folex/ Def, Dropp/Free Fall, Ginstar, Aim, or ET. Plants respond by producing ethylene, which causes the formation of the abscission layer at the base of the leaf petiole. High rates of these materials kill the plants and slow or prevent leaf drop, causing more trash in the lint during the picking operation. Prep, Pluck, and Ethephon 6 are ethephon materials and are hormonal defoliants. The ethephon products release ethylene, which stimulates further ethylene production in the bolls and leaves. Dropp is an example of a growth hormone called cytokinin, which promotes ethylene production in cotton. These materials are compatible in tank mixes that aid the defoliation process. Under cool conditions, use of petroleum-based crop oils has been shown to improve performance. Use of crop oils under high temperatures may result in leaf sticking because plants are killed before the abscission layer has formed.

There is no best harvest aid material that defoliates, stimulates boll opening, prevents regrowth, and performs equally well under hot or cool and dry or moist conditions. Combinations of products can result in good performance under a broad range of conditions that normally occur in Florida. All the harvest aid chemicals have a significant reduction in activity at $60^{\circ} \mathrm{F}-65^{\circ} \mathrm{F}$. Dropp is the most temperature dependent of the defoliants. The least temperature-dependent chemicals are Def 6 or Folex, both of which provide adequate activity at temperatures of $55^{\circ} \mathrm{F}$. Ethephon (Prep, Pluck, Ethephon) is intermediate in activity at cool temperatures.

Finish 6 Pro and FirstPick are combination materials that defoliate and are used primarily for accelerating boll opening. Both of these materials are widely used and provide faster boll opening than equivalent rates of ethephon. However, after two weeks, Finish 6 Pro and FirstPick show little difference in opening over ethephon. DEF/Folex, Dropp/Free Fall, Ginstar, Aim, and ET can be added to these materials for better performance based on the needs of defoliation or regrowth suppression.

Any material can easily be used to defoliate a mature cotton crop with good boll load, low amounts of available soil moisture and nitrogen, and little new growth at defoliation. By contrast, fields with green, actively growing leaves and new blooms because of excess fertility and moisture can be more difficult to defoliate, and regrowth may occur. 
Regrowth suppression is usually accomplished with Dropp as long as temperatures are above $60^{\circ} \mathrm{F}-65^{\circ} \mathrm{F}$. If temperatures drop below this range, glyphosate products may be the best choice for regrowth suppression on non-Roundup Ready cotton. Glyphosate in combinations with Def (as well as with combinations of Dropp and Def) has been shown to do a satisfactory job of defoliating cotton with no more and sometimes less desiccation.

Paraquat will desiccate regrowth to prevent staining of the lint and heat problems in the modules. However, paraquat can freeze unopened bolls, so all mature bolls should be open before using paraquat. Generally, trash from desiccation can be removed in the ginning process, but stains cannot.

Perhaps the most important factor to consider when timing the use of defoliants is determining if unopened bolls are harvestable. Mature bolls will be too hard to dent when squeezed with your hand. These bolls cannot be cut easily with a knife, lint strings out when the boll is sliced, and seed coats are yellow to tan in color. Bolls that set late in the season where there is adequate or excessive moisture and nitrogen should not overly influence the timing of harvest aid application because of the potential loss of large, mature bolls at the bottom of the plant. Late, top bolls are often small and may be damaged by frost and contribute little to yield.

\section{Cotton Defoliation/Harvest}

\section{Aid Suggestions}

The following tables contain general guidelines for harvest aid application. Specific rates should be adjusted according to temperature, humidity, day length, plant leaf condition and maturity, expected weather, and desired effects, such as defoliation, regrowth control, boll opening, and/or weed control. Defoliants should be applied in a minimum spray volume of $5 \mathrm{gal} / \mathrm{A}$ by air and $10 \mathrm{gal} / \mathrm{A}$ by ground. However, for ground applications spray volumes of 15-20 gal/A are desirable for better coverage. Fields should fit into one of the following categories based on temperature and crop conditions. (Pesticide rates are in amount of product per acre or as a percentage of the total spray solution.) 
Table 1. Early season programs (high $90^{\circ} \mathrm{F}$ plus, low $70^{\circ} \mathrm{F}$ plus)

\begin{tabular}{|c|c|c|c|}
\hline Defoliation Only & $\begin{array}{l}\text { Defoliation and Regrowth } \\
\text { Control }\end{array}$ & Defoliation and Boll Opening & $\begin{array}{l}\text { Defoliation, Boll Opening and } \\
\text { Regrowth Control }\end{array}$ \\
\hline $\begin{array}{l}\text { DEF/Folex at } 1-1.5 \mathrm{pt} \\
\text { (reduce to } 1 \mathrm{pt} \text { if above } \\
94^{\circ} \mathrm{F} \text { ) } \\
\text { Aim at } 1.6 \mathrm{fl} \mathrm{oz}+\mathrm{NIS} \text { at } \\
0.25 \% \mathrm{v} / \mathrm{v} \\
\text { Resource at } 4-8 \mathrm{fl} \mathrm{oz}+ \\
1 \text { pt crop oil } \\
\text { Blizzard at } 0.5-0.6 \mathrm{fl} \mathrm{oz} \\
+ \text { crop oil at } 1 \% \mathrm{v} / \mathrm{v} \\
5 . \text { ET at } 1.5-2.75 \mathrm{fl} \mathrm{oz}+ \\
\text { crop oil at } 0.5 \% \mathrm{v} / \mathrm{v}\end{array}$ & 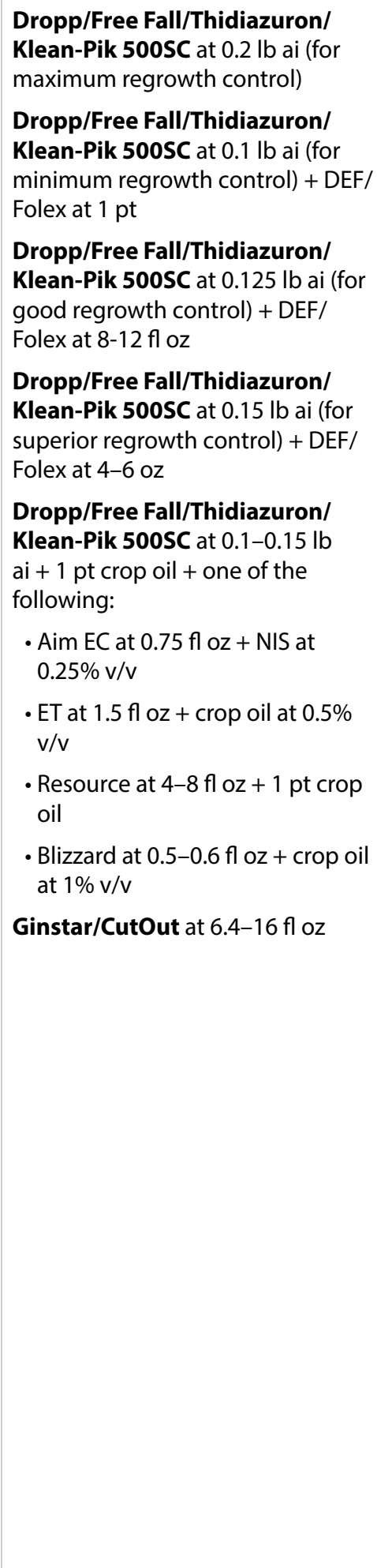 & 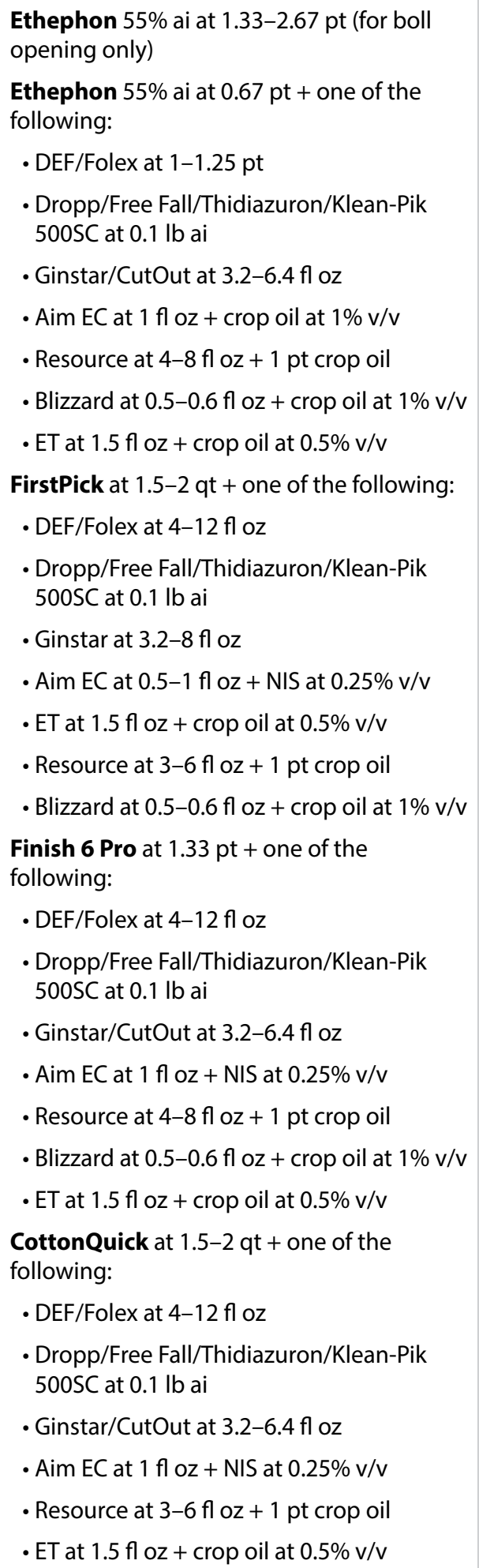 & 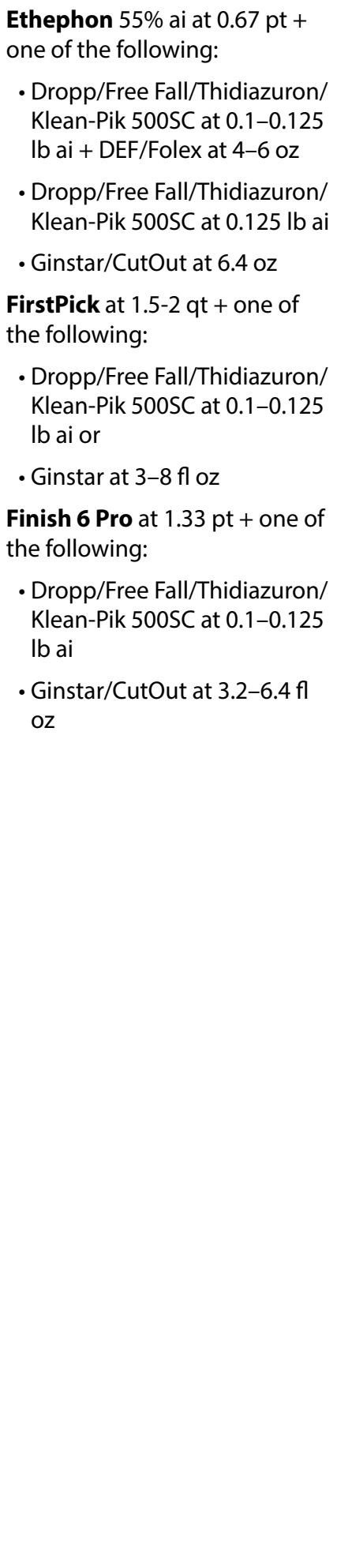 \\
\hline
\end{tabular}


Table 2. Mid-season programs (high $80^{\circ} \mathrm{F}-89^{\circ} \mathrm{F}$ plus, low $60^{\circ} \mathrm{F}-70^{\circ} \mathrm{F}$ )

\begin{tabular}{|c|c|c|c|}
\hline Defoliation Only & $\begin{array}{l}\text { Defoliation and Regrowth } \\
\text { Control }\end{array}$ & Defoliation and Boll Opening & $\begin{array}{l}\text { Defoliation, Boll Opening, } \\
\text { and Regrowth Control }\end{array}$ \\
\hline $\begin{array}{l}\text { DEF/Folex at } 1-1.5 \mathrm{pt} \\
\text { Aim EC at } 0.75-1.6 \mathrm{fl} \mathrm{oz}+ \\
\text { crop oil at } 1 \% \mathrm{v} / \mathrm{v} \\
\text { Finish } 6 \text { Pro at } 1.33-2 \mathrm{pt}+ \\
\text { DEF/Folex at } 6-8 \mathrm{oz} \\
\text { ET at } 1.5-2.75 \mathrm{fl} \mathrm{oz}+\mathrm{crop} \\
\text { oil at } 0.5 \% \mathrm{v} / \mathrm{v}\end{array}$ & $\begin{array}{l}\text { Dropp/Free Fall/Thidiazuron/ } \\
\text { Klean-Pik 500SC at } 0.2 \mathrm{lb} \text { ai } \\
\text { Dropp/Free Fall/Thidiazuron/ } \\
\text { Klean-Pik 500SC at } 0.125-0.14 \\
\text { lb ai + one of the following: } \\
\text { - DEF/Folex at } 0.5-1.0 \mathrm{pt} \\
\text { - ET at } 1.5 \mathrm{fl} \text { oz + crop oil at } \\
0.5 \% \mathrm{v} / \mathrm{v} \\
\text { - Aim EC at } 0.75-1 \mathrm{fl} \mathrm{oz}+\mathrm{crop} \\
\text { oil at } 1 \% \mathrm{v} / \mathrm{v} \\
\text { - Resource at } 4-8 \mathrm{fl} \mathrm{oz}+1 \mathrm{pt} \\
\text { crop oil } \\
\text { - Blizzard at } 0.5-0.6 \mathrm{fl} \mathrm{oz}+\mathrm{crop} \\
\text { oil at } 1 \% \mathrm{v} / \mathrm{v} \\
\text { Ginstar at } 6.4-16 \mathrm{fl} \mathrm{oz}\end{array}$ & 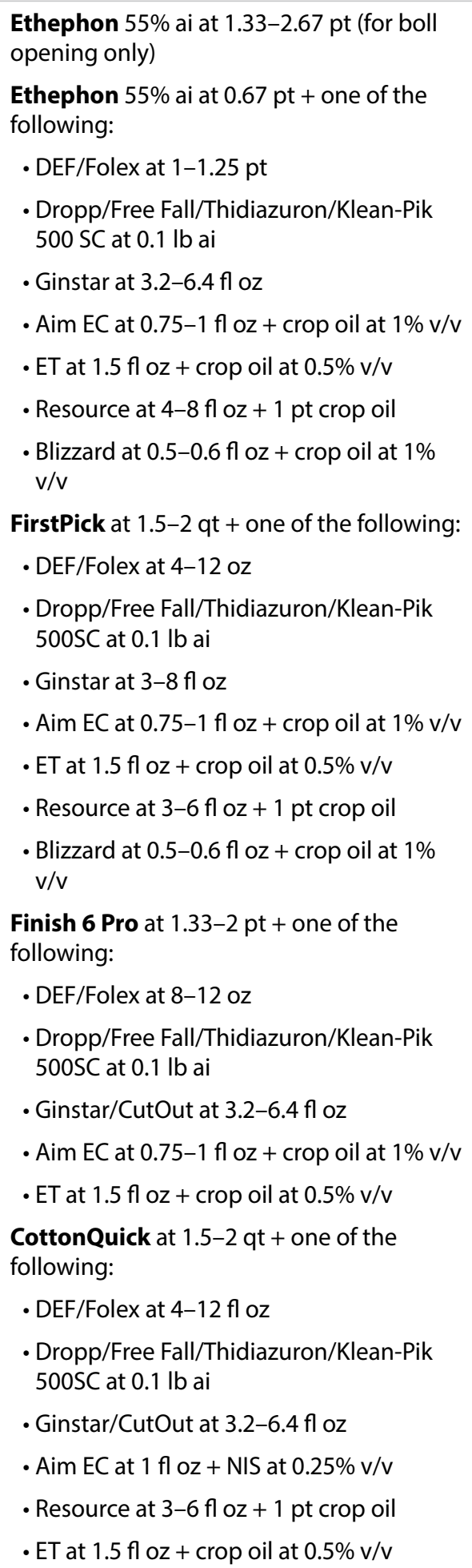 & 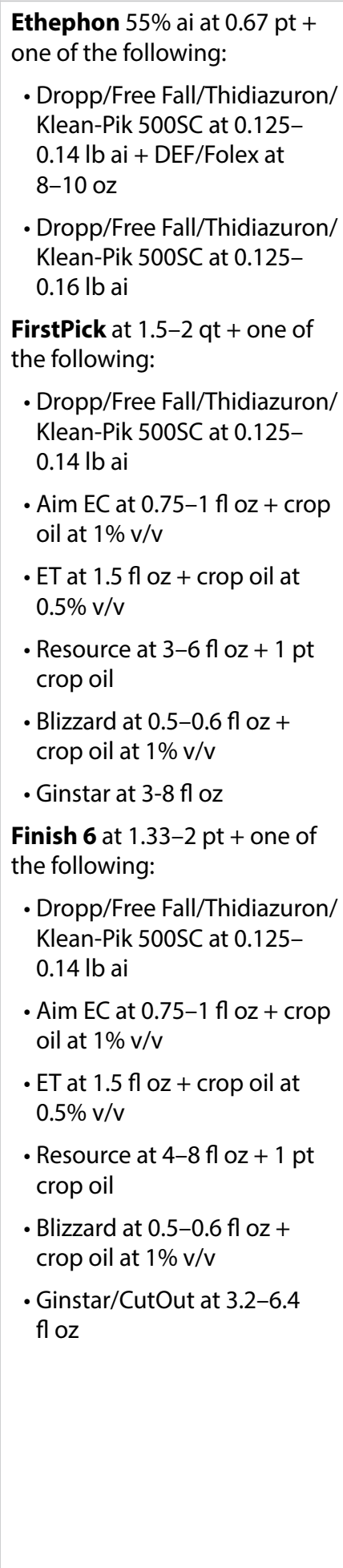 \\
\hline
\end{tabular}


Table 3. Late season programs (high below $80^{\circ} \mathrm{F}$, low below $60^{\circ} \mathrm{F}$ )

NOTE: Under these conditions, cotton should often be preconditioned and then defoliated (see Section IV) or routinely defoliated with combinations, which include ethephon.

\section{Defoliation Only \\ DEF/Folex at $1.5 \mathrm{pt}+$ Paraquat at 3-8 oz}

Ginstar/CutOut at 6.4-12 $\mathrm{fl} \mathrm{oz}$

Finish 6 at $11-16 \mathrm{oz}+\mathrm{DEF} /$ Folex at 6-12 oz

Aim EC at $1.6 \mathrm{fl} \mathrm{oz}+$ crop oil at $1 \% \mathrm{v} / \mathrm{v}$

ET $1.5-2.75 \mathrm{fl} \mathrm{oz}+$ crop oil at $0.5 \% \mathrm{v} / \mathrm{v}$

Resource at 4-8 fl oz + 1 pt crop oil

Blizzard at $0.5-0.6 \mathrm{fl} \mathrm{oz}+$ crop oil at $1 \% \mathrm{v} / \mathrm{v}$

\section{Defoliation and Boll Opening}

Ethephon 55\% ai at 1.33-2.67 pt (for boll opening only)

Ethephon $55 \%$ ai at $0.67 \mathrm{pt}+$ one of the following:

- DEF/Folex at 1-1.5 pt

- Ginstar at 3.2-6.4 $\mathrm{fl} \mathrm{oz}$

- Aim EC at $1 \mathrm{fl} \mathrm{oz}+$ crop oil at 1\% v/v

- ET at $1.5 \mathrm{fl} \mathrm{oz}+$ crop oil at $0.5 \% \mathrm{v} / \mathrm{v}$

- Resource at 4-8 fl oz + 1 pt crop oil

- Blizzard at 0.5-0.6 fl oz + crop oil at 1\% v/v

FirstPick at 1.5-2 qt + one of the following:

- DEF/Folex at 1-1.5 pt

- Ginstar at 3-8 fl oz

- Aim EC at $1 \mathrm{fl} \mathrm{oz} \mathrm{+} \mathrm{crop} \mathrm{oil} \mathrm{at} \mathrm{1 \%} \mathrm{v/v}$

- ET at $1.5 \mathrm{fl} \mathrm{oz}+$ crop oil at $0.5 \% \mathrm{v} / \mathrm{v}$

- Resource at 3-6 fl oz + 1 pt crop oil

- Blizzard at 0.5-0.6 fl oz + crop oil at 1\% v/v

Finish 6 Pro at 2-2.67 pt + one of the following:

- DEF/Folex at 1-1.5 pt

- Ginstar/CutOut at 3.2-6.4 fl oz

- Aim EC at $1 \mathrm{fl} \mathrm{oz}+$ crop oil at 1\% v/v

- Resource at 4-8 fl oz + 1 pt crop oil

- Blizzard at 0.5-0.6 fl oz + crop oil at $1 \% \mathrm{v} / \mathrm{v}$

- ET at $1.5 \mathrm{fl} \mathrm{oz}+$ crop oil at $0.5 \% \mathrm{v} / \mathrm{v}$

CottonQuick at 1.5-2 qt + one of the following:

- DEF/Folex at 4-12 $\mathrm{fl} \mathrm{oz}$

- Dropp/Free Fall/Thidiazuron/Klean-Pik 500SC at $0.1 \mathrm{lb}$ ai

- Ginstar/CutOut at 3.2-6.4 fl oz

- Aim EC at $1 \mathrm{fl} \mathrm{oz}+$ NIS at $0.25 \% \mathrm{v} / \mathrm{v}$

- Resource at 3-6 fl oz +1 pt crop oil

- ET at $1.5 \mathrm{fl} \mathrm{oz}+$ crop oil at $0.5 \% \mathrm{v} / \mathrm{v}$ 
Table 4. Preconditioning programs

NOTE: Fields with dense canopy of foliage and significant numbers of green bolls may require two applications. The goal is to remove much of the foliage with an initial application, exposing unopened bolls. The follow-up application should be made 7-10 days later, when sufficient leaf drop has occurred to allow spray coverage of bolls with ethephon, FirstPick, or Finish 6 Pro.

\section{Initial Preconditioning Treatment}

DEF/Folex at 1-1.5 pt

Ethephon $55 \%$ ai at $0.67-1.33 \mathrm{pt}$

ET at $1.5-2.75 \mathrm{fl} \mathrm{oz}+$ crop oil at $0.5 \% \mathrm{v} / \mathrm{v}$

Aim EC at $1.6 \mathrm{fl} \mathrm{oz}+$ crop oil at $1 \% \mathrm{v} / \mathrm{v}$

Resource at 4-8 fl oz + 1 pt crop oil

Blizzard at $0.5-0.6 \mathrm{fl} \mathrm{oz}+$ crop oil at $1 \% \mathrm{v} / \mathrm{v}$

Follow-Up Treatments Should Include Boll Openers with Harvest Aid Mixtures Listed in Sections I, II, and III.

\section{General Notes}

Beware of off-target movement of harvest aid products, especially with aerial applications. Significant problems have been observed with mixtures that include glyphosate, paraquat, or Aim.

Dropp is sensitive to wash-off if rain occurs within six hours of application; addition of DEF/Folex improves rainfastness. Ammonium sulfate at $2 \mathrm{lb} / \mathrm{A}$ often improves activity of Dropp/Thidiazuron/Klean-Pik 500SC. DEF/Folex plus Dropp combinations have a tendency to cause "leaf sticking" when temperatures exceed $94^{\circ} \mathrm{F}$, in combinations with spray adjuvants, or when rates are too high. Consider reducing rates by $10 \%-20 \%$ when temperatures exceed $94^{\circ} \mathrm{F}$. Regrowth control is minimal with Dropp/Thidiazuron/ Klean-Pik 500SC rates below $0.1 \mathrm{lb} / \mathrm{A}$ or Ginstar/CutOut rates below $6.4 \mathrm{fl} \mathrm{oz}$. Ginstar and CutOut includes the same active ingredients as Dropp and diuron.
Adding spray adjuvant may enhance activity of treatments when temperatures are low. However, adjuvants may sometimes cause "leaf sticking," and these products should be used with caution early in the season.

Addition of paraquat at 1-4 $\mathrm{fl} \mathrm{oz}$ may aid defoliation and weed desiccation with standard harvest aid mixtures. Off-target movement may cause injury to sensitive plants, such as pine trees. 
Table 5. Harvest aid weed management

1. Paraquat at 1-4 $\mathrm{fl} \mathrm{oz}$ in combination with standard defoliant mixtures.

Use lowest rate during warm temperatures. Avoid off-target drift, especially to pines.

2. Aim at $0.5 \mathrm{floz}+$ crop oil at $1 \% \mathrm{v} / \mathrm{v}$. Effective on morningglory and coffee senna.

3. a) Defoliate, then b) Desiccate with Paraquat as listed below.

Table 6. Desiccants for cotton harvest preparation

\begin{tabular}{|c|c|c|c|}
\hline Desiccate & lb A/gal & $\begin{array}{c}\text { Formulation } \\
\text { Rate/Acre }\end{array}$ & Ground \\
\hline Paraquat & & $1-4 \mathrm{fl} \mathrm{oz}^{1}$ & $10-20$ \\
\hline
\end{tabular}

${ }^{1}$ For addition to defoliant mixtures in cotton at least $75 \%$ open. Improves activity in colder, late-season conditions. May cause crop desiccation $\left(90^{\circ} \mathrm{F}\right.$ and above) and damage to immature bolls.

${ }^{2}$ For desiccation of weeds and cotton regrowth after defoliation. Rates of 8-16 oz are usually sufficient. Add surfactant at 1-2 qt/100 gals spray solution. Be prepared to harvest in a timely manner to minimize bark problems.

Table 7. Performance rating of harvest aids by function ( $P=$ poor, $F=f a i r, G=g o o d, E=e x c e l l e n t)$

\begin{tabular}{|c|c|c|c|c|c|}
\hline \multirow[t]{2}{*}{ Product } & \multicolumn{5}{|c|}{ Function } \\
\hline & $\begin{array}{l}\text { Remove } \\
\text { Mature } \\
\text { Foliage }\end{array}$ & $\begin{array}{c}\text { Remove } \\
\text { Juvenile } \\
\text { Foliage }\end{array}$ & Open Bolls & $\begin{array}{l}\text { Suppress } \\
\text { Regrowth }\end{array}$ & $\begin{array}{c}\text { Desiccate } \\
\text { Weeds }^{2}\end{array}$ \\
\hline Aim/ET & G & G-E & $\mathrm{P}$ & $\mathrm{P}$ & $\mathrm{F}$ \\
\hline DEF/Folex & $\mathrm{G}-\mathrm{E}$ & $\mathrm{P}-\mathrm{F}$ & $\mathrm{P}$ & $\mathrm{P}$ & $\mathrm{P}$ \\
\hline Dropp/Thidiazuron/Klean-Pik & G-E & G & $\mathrm{P}$ & G-E & $\mathrm{P}$ \\
\hline Ginstar/CutOut & G-E & G & $\mathrm{P}$ & G-E & $\mathrm{P}$ \\
\hline Ethephon ${ }^{1}$ & F-G & P-F & $\mathrm{E}$ & $P$ & $\mathrm{P}$ \\
\hline Paraquat & $\mathrm{F}$ & $\mathrm{F}$ & $\mathrm{F}$ & $\mathrm{P}$ & G \\
\hline FirstPick & G & P-F & $\mathrm{E}+$ & $P$ & $\mathrm{~F}$ \\
\hline Finish & G-E & P-F & $\mathrm{E}+$ & $\mathrm{F}$ & $\mathrm{P}$ \\
\hline
\end{tabular}

